\section{Prof. D. H. Robertson}

DR. D. H. Robertson has been appointed to the Sir Ernest Cassel chair of economics, with special reference to banking and currency, tenable at the London School of Economics. He will take up his duties on January 1, 1939. The Sir Emest Cassel chair of economics, instituted in 1920, was previously occupied by Prof. T. E. Gregory, who resigned in December 1937 to take up the office of economic adviser to the Government of India. Dr. D. H. Robertson is at present reader in economics in the University of Cambridge, and has been a fellow of Trinity College since 1914. His work on industrial fluctuation and on the theory of money has given him an international reputation, recognized by the conferment on him of honorary degrees by the Universities of Amsterdam and Harvard. He has been a member of the Economic Advisory Council since 1936. He co-operated with Prof. A. L. Bowley in the Economic Survey of India, 1934. Among his published works are "A Study of Industrial Fluctuations" (1915), "Money" (1922), and "Banking Policy and the Price Level" (1926).

\section{New Wing of Queen Mary College, London}

ON October 12, the Chancellor of the University of London formally opened the new west wing of Queen Mary College, which has been erected upon the site of the Winter Garden of the old People's Palace. The spacious Zoology Department, fully equipped for modern requirements, occupies the top of the new wing, and apart from the usual laboratories, museum, etc., possesses a special aquarium room with marine and freshwater aquaria, and two animal rooms. The removal of the Arts Departments to the lower floors of this new wing has provided room for considerable extensions of the Departments of Botany, Geology and Physics, which occupy the east wing, although the completion of the Physics Department awaits the third and final phase of the building programme. The College is now provided nearly throughout with up-to-date modern laboratories, several of which are equipped for special lines of research. In declaring the new buildings open, the Chancellor expressed the hope that funds would soon become available for completing the building programme of the College.

\section{Rothamsted Centenary: Inaugural Meeting}

WHILE the experimental fields at Rothamsted are probably the best known and the most interesting in the world, the laboratories, farm buildings and equipment are admittedly not up to the standard of many of the Continental or American stations, and do not allow of anything like so much scientific assistance to the farmer as should in these difficult times be available. The Committee of Management is taking advantage of the approaching centenary to remedy these various deficiencies and is hoping to raise a fund of $£ 125,000$, of which $£ 80,000$ would be used for buildings and equipment and $£ 45,000$ for addition to endowment so as to provide for upkeep of fabric and salary augmentations. The work will proceed in three stages. The first is the building of the new chemical and bacteriological laboratories, pot culture houses and farm buildings; this will cost about $£ 45,000$ of which, however, only $£ 30,500$ is drawn from the centenary fund, the remainder being provided by the Ministry of Agriculture. The second stage will be the building of the library at a cost of $£ 20,000$; and the third the erection of a new block to house the Imperial Soil Bureau, the Statistical Department, the administration and extension staff, a conference hall and staff common rooms : this will

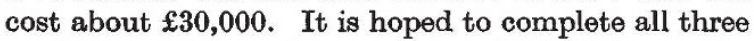
parts before the centenary occurs in 1943 , hence the work is being put in hand as early as possible. This is being done partly also for the convenience of those who wish to spread their donations over a period of years. The scheme is being inaugurated at a meeting to be held on November 1 at the Royal Society's rooms, when His Royal Highness the Duke of Kent will preside, and when it will be announced that His Majesty the King, through the Duchy of Cornwall, will open the subseription list.

\section{Tide Mills of England and Wales}

IN a very well illustrated lecture to the Newcomen Society on October 12, entitled "The Tide Mills of England and Wales", Mr. Rex Wailes gave a survey of all the mills of which he had been able to find any traces. In the course of two years he had visited the sites of twenty-three mills, and of these ten were still worked by the tides. Starting with the county of Suffolk, he described the mill at Woodbridge on the Deben Estuary, first mentioned about 1170. This mill is served by a $3,100,000$ sq. ft. pond with a sixfoot head. The water-wheel is $20 \mathrm{ft}$. in diameter and $5 \mathrm{ft} .10 \mathrm{in}$. in width and it is mounted on a 22 -in. square oak shaft. It drives four pairs of mill stones controlled by a single pair of governors, the only instance of its kind. There are early references to several tide mills in London but the only ones at work are at the Three Mills Distillery, Bromley-byBow. Here in the House Mill are four water-wheels, and in the Clock Mill, three water-wheels, all about $20 \mathrm{ft}$. in diameter, driving in all eighteen pairs of stones for grinding maize, barley and other cereals for the production of spirits. The mills are semi-tidal, being worked as the water flows outward from the River Lea. Other mills still working are at Stambridge, in Essex, Beaulieu and Eling in Hampshire, Carew and Pembroke in Wales, and Emsworth in Sussex. The paper is printed and illustrated in Engineering for October 14.

\section{Associated Learned Societies of Liverpool}

THE triennial public exhibition and soirée organ. ized by the Associated Learned Societies of Liverpool and District to illustrate the progress in science and education since their last exhibition in 1935 was held in the City Technical College on October 22. During the course of the exhibition, Prof. E. W. Marchant gave a lecture on "Television", H. Kendrick on "Changing India", W. H. Watts on "The 
Moon", D. Caradog Jones on "The Changing Population of Merseyside", Prof. J. T. Craig on "Veterinary Pathology", and a number of shorter talks were given in the individual rooms. The Institute of Chemistry and the Society of Chemical Industry exhibited process demonstrations of artificial silk spinning, products obtainable from cotton seed, demonstrations of the action of dirt particles under the influence of electrical forces, dyeing and armourplate glass; the British Association of Chemists exhibited a combined temperature and humidity recorder, smoke density determination apparatus and samples from the plastics industry. The Liverpool Biological Society's room included a demonstration exhibit by Prof. J. H. Orton on his Dee fisheries work, Dr. R. J. Daniel on pearl-formation, and Mrs. Bisbee on the ductless glands. Mr. Eric Hardy had arranged a special "Country-Side" Room with Nature films, photographs, habitat groups of British birds and mammals, bird migration ('ringing') and flight (bird-wing) displays, illuminated natural colour lantern slides, bird sanctuary devices and maps of local bird distribution. The exhibition also included natural colour films, an ingenious microprojector by Mr. A. V. Wilkinson, Dr. Glynn Morris's geological collection, and in the Engineering Society's room, a trafficator for cyclists invented by $\mathrm{Mr}$. A. Robins.

\section{Indian Adult Education}

From the National Adult School Union we have received a copy of an appeal by its International Committee for funds to assist in the development of adult education work in India. The appeal is countersigned by Mr. Banning Richardson, as president of the Indian Adult Education Society and honorary general secretary, All-India Adult Education Conference Committee. This committee has undertaken to investigate all the adult education activities which are being carried on in India and to call a conference for the early part of 1939. Annexed to the appeal is a leaflet which mentions, as indicative of the character of the work now carried on by the Indian Adult Education Society: the teaching of improved methods of handicrafts to undergraduates of the University of Delhi with the intention that during the vacations this instruction should be passed on to their rural relations and friends; "literacy work" ; a regular service of rural broadcasting; the teaching of scholastic subjects to matriculates, who have not been able to continue their studies at a university ; and the giving of instruction to members in their own religion by the most capable believer in that faith available. Of this last, it is claimed that an improved relationship between the followers of the different religions has resulted. Nothing is said about the utilization of the movement as an instrument of political propaganda, but reference is made to the fact that in the Central Provinces, recently described in The Hindu as "a thoroughly congressminded province", the Minister of Education and Vice-Chancellor of the University have associated themselves with it.

\section{Royal Society of Science, Bombay}

SrNCE its opening in 1920, the Royal Institute of Science, Bombay, has been recognized as the foremost college in the Presidency for the training of science students. The late Dr. A. N. Meldrum, the first principal and professor of organic chemistry, realized the importance of its being not merely an institution for the training of undergraduate students, but that it should also be an active centre of research. He was fortunate in having the support of an enthusiastic staff, and during the period of his principalship a large number of students were trained in the methods of research both in the physical and natural sciences. We have now before us the triennial report of the Institute covering the years 1934-37, and we note with pleasure the continued advancement of the Institute under the energetic and enlightened leadership of its present principal, Prof. T. S. Wheeler. The total number (315) of full-time students is not large, and of these no fewer than 94 are engaged in post-graduate work, which indicates the importance attached to original work.

DURING the triennium dealt with in the report, 159 original papers have been published of which the majority (102) come from the two departments of chemistry. Whilst, as is natural, their contents are of varying value, Prof. T. S. Wheeler's contributions to the theory of liquids and Prof. R. H. Dastur's work on plant metabolism have attracted widespread attention. In its recent visit to Bombay, the British science delegation had the opportunity, all too short, of visiting the Institute and of seeing something of the work which is being so actively pursued. Contrary to the experience elsewhere in India, no difficulty has been encountered in finding employment for students, of whom only 0.6 per cent were unemployed, whilst 21.8 per cent had obtained industrial posts. It is very much to be hoped that no considerations of economy will be allowed to weaken the activities of the Institute since, to the students now under training there, the industries of the Bombay Presidency must largely look for their future advancement.

\section{Acquisitions at the British Museum (Natural History)}

THRovar the kindness of the Rev. T. H. Wilson, of Inkongo in the Sankuru district of the Congo, the Museum has received a female specimen of the recently discovered peacock-like bird, Afropavo congensis. This bird was first discovered by Dr. James P. Chapin, of the American Museum of Natural History, New York, in 1936, who found two mounted examples in the Ethnological Department of the Tervueren Museum, Brussels, where they had been overlooked. Later the authorities of that Museum received further specimens from the Congo. Dr. Chapin visited the area and his native hunters brought in two more, while he himself had a fleeting view of one bird in the forest. The interesting feature of this bird is that in some of its characters it resembles the peacock, a bird which is confined to Asia. Specimens of diamondiferous gravels and concentrates have been 